the newspaper press of the United States ended by according to the work of the meeting serious and satisfactory treatment. We commend this report to any one who wishes to learn in a pleasant and easy manner of the extensive and varied work that is carried out by a modern museum, and to those museum curators who may desire inspiration in their daily labours.

\title{
Presentation to Sir Edward Sharpey Schafer, F.R.S.
}

$\mathrm{R}$ ATHER more than a year ago the suggestion was made that the Edinburgh meeting of the British Association would form a fitting occasion for the presentation to Sir Edward Sharpey Schafer of some token of their esteem from his present and past demonstrators and fellow research workers in London and Edinburgh. As so many of those who had been trained under Sir Edward now occupy posts in distant lands it was found impossible to make the necessary arrangements for the presentation at that early date.

Prof. Halliburton, however, made a statement at one of the largely-attended meetings of the Physiology Section of the Association, expressing the desire of all who had been associated with their old master in the prosecution of physiological research to present him with some mark of their esteem and affection, and indicated the form it would probably take.

Finally, it was arranged that the presentation should take the form of a fullsized plaque (Fig. I), and that a medal replica should be presented to each of the many subscribers. The medal shows in bold relief the head and shoulders of Sir Edward, and bears on the reverse the inscription:--

Sodali bene merito

Sodales bene volentes MCMXXII

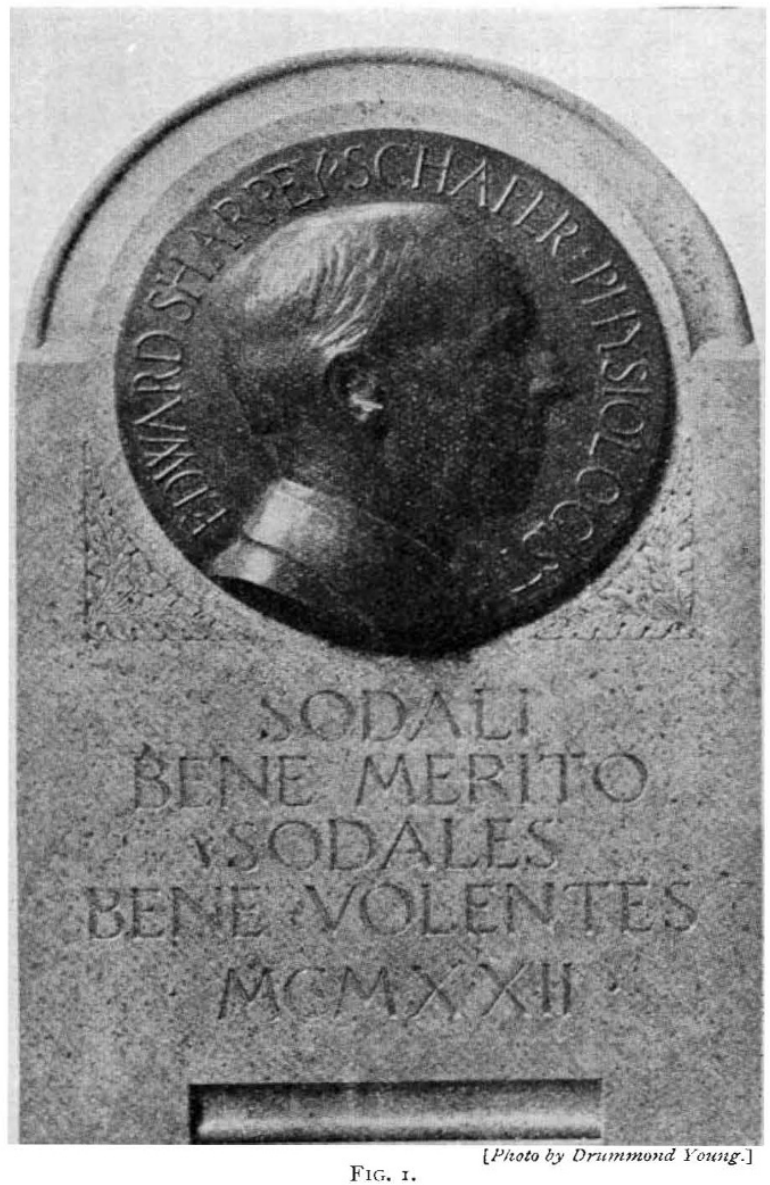

and, moreover, an excellent portrait. The large bronze plaque from which the medal was reduced has been mounted on stone, with the inscription underneath it (Fig. I). Sir Edward feels that it should eventually come to the University of Edinburgh, but at present it remains in the sculptor's studio as he wishes to exhibit it at the Royal Scottish Academy.

The large list of subscribers includes many of the leaders in physiology and other branches of medical science in this and other lands, a few of whom may be namedBayliss, Rose Bradford, Halliburton, L. Hill, MacWilliam, Mott,Starling, in this country; and Hunter and Tait (Canada), Jolly (S. Africa), Malcolm and Mackenzie (New Zealand), Addis and S. Simpson (U.S.A.), Row (India), Itagaki and others (Japan). Among the original subscribers were two of great distinction who have unfortunately passed away-A. D. Waller and Benjamin Moore.

The recognition of Sir Edward Sharpey Schafer's invaluable services to physiology by those who have worked with him in the laboratory is a matter for sincere congratulation in which all who have the interests of the development of medical science at heart will join. All

The work was entrusted to Mr. C. d'O. Pilkington Jackson, A.R.B.A., sculptor, and has been carried out in an eminently satisfactory way. It is most artistic will unite in expressing the hope that he has still before him many years in which he will continue his life-work.

\section{Obituary.}

\section{F. B. Bryant.}

$\mathrm{W}$ E regret to record the death, on November 28 , at the age of sixty-three, of Mr. Frederick Beadon Bryant, formerly Inspector-General of Forests to the Government of India. Mr. Bryant received his professional training at Nancy, joined the Indian Forest
Service in $\mathrm{r} 88 \mathrm{r}$, and was posted to the North-West Provinces and Oudh. Some of the earlier years of his service were spent in the preparation of working plans for the important sub-Himalayan forests lying between the Ganges and the Sarda rivers. This early training, together with some years of successful executive work in his province, marked him out subsequently for the 
post of Assistant Inspector-General of Forests and Superintendent of Forest Working Plans, which he held for three years from I896. After holding successively the posts of Conservator of Forests in the Punjab and Burma and Chief Conservator of Forests in Burma, he became Inspector-General of Forests to the Government of India, an appointment which he held from 1908 till $\mathrm{I}_{913} 3$, when he retired from the service of Government. Mr. Bryant succeeded to this post at an important period in the history of his department. The Forest Research Institute at Dehra Dun had been established two years previously on the initiative of his predecessor, Mr. (now Sir Sainthill) Eardley-Wilmot. It fell to Mr. Bryant to guide the destinies of the Institute in its earlier years, and his handling of this task was marked by sound common sense and careful judgment. A man of cheerful personality, he made a popular chief, and enjoyed to an unusual extent the goodwill of his department. In recognition of his services to Government he was awarded the C.S.I. in I9II. He is survived by a widow and grown-up family, to whom we extend our sympathy. He had the misfortune to lose one of his sons on active service during the war.

M. E. Bouty, professor of experimental physics at the Sorbonne and member of the Academy of Sciences, died in Paris on November 5 in his seventy-seventh year. To the present generation of physicists in this country he was probably best known as the editor of the Journal de Physique and of the Annales de Physique, but to those of thirty or forty years ago he was the joint author of a text-book on physics much appreciated by all who wished to keep themselves up-to-date-the "Cours de physique de l'École Polytechnique" and its supplements. His principal published researches deal with, problems connected with the passage of electricity through liquids and gases, but these memoirs by no means represent the whole of his work in the field of research. He succeeded in building up a school of research at the Sorbonne, and much work published by his pupils owed its inspiration to Prof. Bouty.

The death, on December ro, is announced of Mr. Edward Degen, sometime of the staff of the British Museum and the Melbourne Museum. Mr. Degen was born in Basle in March 1852, and was educated in Basle and Paris. He travelled extensively and collected zoological material in West Africa, Uganda, Abyssinia, and Sakhalin. He was an expert taxidermist and had paid considerable attention to the moulting of birds, and to vertebrates generally. He was a Swiss and a citizen of Basle.

\section{Current Topics and Events:}

IT is stated by the Paris correspondent of the Times that the centenary of Pasteur was celebrated officially during the afternoon of December 26 at the Academy of Medicine. The French Minister for Health, M. Paul Strauss, was present, and a number of eminent medical men spoke on Pasteur's life and work. The Under-Secretary of Posts and Telegraphs has approved a design, showing a profile of Pasteur's head, for a special fifty-centimes postage stamp to be issued during the coming centenary celebrations.

IT may be remembered that, early in the present year, a proposal to prohibit the teaching of evolution in the schools of the State of Kentucky failed to pass the State legislature by one vote. In an article which appeared in NATURE of May 27 (vol. I09, p. 669), the opinion was expressed that further agitation with the same object might be looked for in the near future. That this apprehension was but too well founded appears by the fact that a "State-wide meeting of protestant ministers " in Minnesota has lately passed resolutions demanding that "the State shall prove its impartiality toward its citizens by dispensing with a subject (i.e. evolution) that is utterly divisive [sic] ; and is, in the judgment of thousands of its taxpayers, utterly false." A reason given for this remarkable action is that "this hypothesis . . . has increasingly shown itself to be a foe to the Christian faith, denying as it does the veracity of the Scriptures." Such attempts at suppression are completely out-of-date, and the importation of religious intolerance into the question cannot but make the judicious grieve. The Minnesota meeting was perhaps not aware that the Catholic University of Louvain sent a special representative to the Darwin celebration at Cambridge.
YET another appeal has reached us on behalf of the famine-stricken people of Russia, this time from Dr. Nansen's committee by way of the Medical Aid Committee for Sufferers from the Russian Famine. It is addressed primarily to medical men, and, following out, apparently, the principle we have suggested in previous comments on these appeals, of approaching each group or profession on behalf of its co-workers in Russia, it is mainly for the assistance of medical men in Russia. It is stated that the latter, amid thousands of sick and starving people, are helpless for the lack of drugs and medical stores, and medical men here are asked to press for the formation of an international committee on medical relief to fight the effects of the famine. Men of science are needed to attack the sanitary and biological problems with which Russia and, through her, the whole of Europe are confronted. In the meanwhile supplies of medical and other stores will enable Russian doctors to struggle on with their task. Gifts in kind should be forwarded to the Secretary, Medical Aid Committee, 68 Iincoln's Inn Fields, W.C.2 ; contributions in money to the committee's treasurer at the London Joint City and Midland Bank, 6 Chancery Lane, W.C.2.

THe Library Journal for November I contains an article by Mr. E. C. Richardson, director of Princeton University Library, entitled "International Cooperation in Intellectual Work." Mr. Richardson refers to the recent appointment by the League of Nations of a Committee on Intellectual Co-operation, and writes with appreciation of the practical utility of three enterprises which this committee will necessarily take into consideration. Mr. Richardson 